\title{
Problems Faced by Women Entrepreneurs in Kohat City of Khyber Pakhtunkhwa-Pakistan
}

\author{
HafizUllah \\ Institute of Management Sciences, Kohat University of Science \& Technology, Kohat. KPK- \\ Pakistan \\ Zulqarnain Muhammad Ahmad \\ Institute of Management Sciences, Kohat University of Science \& Technology, Kohat. KPK- \\ Pakistan
}

Sheikh Raheel Manzoor

Institute of Management Sciences, Kohat University of Science \& Technology, Kohat. KPK-

Pakistan

\section{Murad Hussain}

Institute of Management Sciences, Kohat University of Science \& Technology, Kohat. KPK-

Pakistan

Muhammad Azam Farooq

Coordinator HRDC IM Sciences, Hayatabad Peshawar. KPK- Pakistan

Accepted: November 2, $2011 \quad$ Published: January 5, 2012

doi:10.5296/ijhrs.v2i1.1241 URL: http://dx.doi.org/10.5296/ijhrs.v2i1.1241

\begin{abstract}
The object of this study is to find out different problems faced by women entrepreneurs in Kohat city of Khyber Pakhtunkhwa-Pakistan. 30 questionnaires were distributed among
\end{abstract}


respondents through simple random sampling method to collect information about female entrepreneurs working in different fields. Results are presented in pie chart form and interpreted through simple average method. Like most of the developing countries, women entrepreneurs in Pakistan and Kohat in particularly face gender base discrimination and suffer from the shortage and little access to resources. Lack of product market information, education and training, assistant from governmental agencies etc. having no encouragement from male family members, and improper networking mechanisms are further problems faced by women entrepreneurs.

Key Words: Women, entrepreneur, female entrepreneurship, Khyber Pakhtunkhwa, business problems.

\section{Introduction:}

Entrepreneurship is about devising and implementing new ideas and practices or improving old ones. It is entrepreneurship that converts an innovation into a sustainable enterprise that generates value. An enterprise is "any entity, new or existing, that provides a new product or service or that develops and uses new methods to produce or deliver existing goods and services at lower cost. Entrepreneur innovate new ways of manipulating nature, and new ways of assembling and coordinating people. Thus, it is important that individuals who have entrepreneurial potential should be encouraged to take their place in the economic process.

Women entrepreneurs do not operate in isolation. They work under the same macro, regulatory and institutional framework as their male counterparts in a free market mechanism in Pakistan. It is necessary to dig deeper to understand the gender biases embedded in society which limit women's mobility, interactions, active economic participation and access to business development services.

The business environment for women in Pakistan reflects the complex interplay of many factors, which fall into two basic categories. The first is made up of social, cultural, traditional and religious elements. This aspect of the environment has taken shape over many centuries. The second group of factors derives from the first group, taking the form of constitutional structures, policy documents, regulatory arrangements and institutional mechanisms. This category is contemporary rather than traditional.

Zahir Ahmad Sulehri (2010) says that "Pakistan's future lies in the hands of its youth, especially young entrepreneurs which compose of approximately 25 million people between the age of 15 and 24. But in Pakistan, young entrepreneurs have to face a number of problems. Economy is a major factor in many problems. On the other hand, lack of management and business skills, poor infrastructure, non-availability of electricity and gas, etc. are basic hurdles for a new comer. Criticism from family and stereotyped society is another fact. Your family should be very supportive especially for female entrepreneurs; otherwise you cannot do anything in this society with ease". 
In Pakistan getting a secured job in any big company is the most desired and logical option for a graduate. Some how we need to change that mentality. Being an entrepreneur is not bad. In fact, it is really good. Currently, the situation in Pakistan is ideal for entrepreneurial ventures especially for young students because Pakistan is the land of opportunity.

Malik Ahmad Jalal, Director of Pakistan Fast Growth 259 (an organization working for promotion of entrepreneurship in developed and developing countries) said that the "solution to Pakistan's economic challenges lies not in foreign lands, but in the entrepreneurial talent of its own citizens" Pakistan Daily (2010).

Zahid Maqbool, President, ICCI said that Pakistan has immense potential for promoting business enterprises as it has a very young and talented manpower along with an ever increasing market for goods and services. He further said that promotion of entrepreneurship will create multiple benefits for the country as it will create jobs, promote business activities and generate more tax revenue for the government.

Moreover he said that there are many challenges being faced by the entrepreneurs in Pakistan like non-availability of business friendly environment, lack of financing facilities, high credit cost, insufficient support and guidance, inconsistent government policies, energy shortage and very high power tariffs etc.These are some of the major challenges that have made things difficult for entrepreneurs and enhanced cost of doing business in Pakistan.

Mr. Anne Habiby, Co-founder of All World Network said that the "Pakistan Fast Growth 25" companies led by dynamic men and women, represents a new future of the country". He said we are honored to be working with JS Bank and other partners to put Pakistan's fast growing entrepreneurs on the global radar screen.

Rehmatullah Javed, Chairman, FPCCI SMEs Committee said that this initiative of All World Network will highlight the role of private sector in generating new ideas, new jobs and new industries.

JS Bank representative said that we need to find and support new business leaders because they are the future of Pakistan's economy.

Source URL: http://www.daily.pk/?p=20735

\section{Perceptions of Women in Pakistan}

The World Bank Country Gender Profile of Pakistan criticize the fact that the status of women in Pakistan is among the lowest in the world (World Bank, 1999) . UNDP (1996) describes the strong "inside/outside" dichotomy in Pakistan, where women are limited to the "inside" space of home and household, embodied in the tradition of veiling. This restricts women's access to education, employment, training opportunities and social services. Social 
disapproval of women working outside the home translates into the invisibility of women in the labor force. Although they participate actively in the family and farm affairs, their unpaid work is perceived as a social duty rather than an economic contribution (Samina, 1997). Stiglitz (1998) said that "gender has expressed grief the poor indicators of Pakistan compared with other developing countries".

\section{Review of literature:}

The four important factors determining economic development are resources, capital, labor and entrepreneurship. According to Hisrich and Peters(1989) "entrepreneurship is the process of creating something of value by devoting the necessary skills, time and effort, and, assuming the accompanying financial and sometimes physical and social risks, to reap the resulting monetary rewards and personal satisfaction". Today, entrepreneurship is becoming increasingly important. Individual, social and environmental factors all have a direct bearing on the entrepreneurial process, its motivation, innovation, continuity and expansion (Bygrave, 1994).

Entrepreneurial activity, which is a value creating process with economic, social and personal satisfaction, has been adopted by more and more women in recent years. This can give them an inbuilt advantage in the entrepreneurial stakes, both in developing and developed countries (Peterson and Weiermair,1998; Sirageldin, Sorkin and Frank,1990). Studies concerned with women entrepreneurs started in the 1980s, and accelerated in the 1990s. However, not only in foreign countries but also especially in Pakistan, the numbers of the studies about the economic, social and cultural aspects of female entrepreneurship are still very limited.

As women's entrepreneurship development theories have emerged primarily from research in developed countries, it is important to examine the extent to which these apply in the context of developing countries such as Pakistan

Most of the emerging theories and prescriptions for success of women's entrepreneurship are derived from the growing body of knowledge comprising of the studies conducted in developed countries (Lerner, Brush and Hisrich,1997). One of the main reasons is the scarcity of research conducted on the topic in developing countries (Allen and Truman, 1993).

Most of this work has been conducted by the international development agencies, which have tended to focus on women's concerns from a 'macro-perspective' (Wees and Romijn, 1987).

Social changes, together with technological and industrial development, attract more and more women to participate in business both in developing and developed countries. Particularly in developed countries an increasing number of women are seeking to become entrepreneurs (Hisrich and Brush, 1988). The USA, Canada and Britain are among the countries in which female entrepreneurship thrives 
Women's productive roles, particularly in business activities, empower them economically and enable them to contribute more to overall growth and to social and political development of their country. However, in many societies such as Pakistan, women are not playing significant role in this regard.

\section{Research Design and Method:}

The research has been designed in a way to cover all the aspects of the Women entrepreneurs about their current situation. While designing the research of this study it was kept in mind that it should serve the purpose practically and should be in line with the objectives of the study. This research is a cross-sectional study that is the data will be gathered only once over a period.

The data is collected from respondents working in different fields through questionnaire backed by interview. Analysis of questionnaires were done through simple average method and presented in Pie charts in order to present specific and accurate information. Apart from the primary data, secondary data will also be used to conduct this research and to make this research effective. Secondary data will be obtained mainly from internet, articles and economic surveys.

\section{DATA ANALYSIS AND INTERPRETATION}

For the research on "What problems faced by Women Entrepreneur in Khyber Pakhtunkhwa?" 30 questionnaires were distributed among Women Entrepreneurs working in different fields in Kohat city of Khyber Pakhtunkhwa. From these Women Entrepreneurs we get a lot of knowledge and this help us to understand different factors which create problems.

\section{1: Motivation for starting the business? [(a) Perceived market opportunity (b) Necessity]}

From the above question, I want to know the motivation for starting the business in Kohat city of KPK-Pakistan. What factors influence them to start their own business? Generally women start or come in to business because of two major factors that is, perceived market opportunity and necessity. Out of 30 respondents $66.67 \%$ said that they start business because they perceive market opportunity and see potential in business, instead $33.33 \%$ respondents said they start business because they want to support there family. 


\section{Macrothink

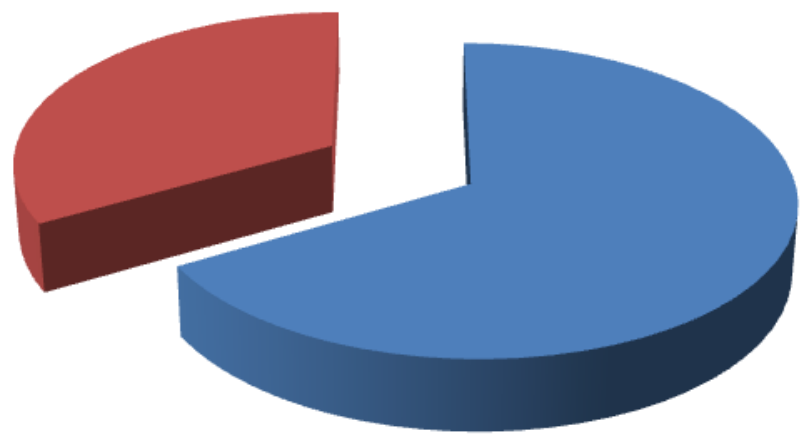

Perceived market opportunity

Necessity

\section{2: Why you have selected this business:}
a) Inherited
b) Skills or qualification
c) Advice of family member

d) Demand in the market

e) Perceived profitability of the product

From above question I got to know that what are the reasons behind the selection and running of the current business like whether they run their business on the basis of skills, demand in market, other people success in that business (role models) because of profitability of business, inherited or advice of family members. Out of 30 respondents about $35 \%$ women select their business on the basis of their skills or qualification, $30 \%$ because of inherited, $20 \%$ demand in the market, $10 \%$ perceived profitability of the product and $5 \%$ advice of family member.

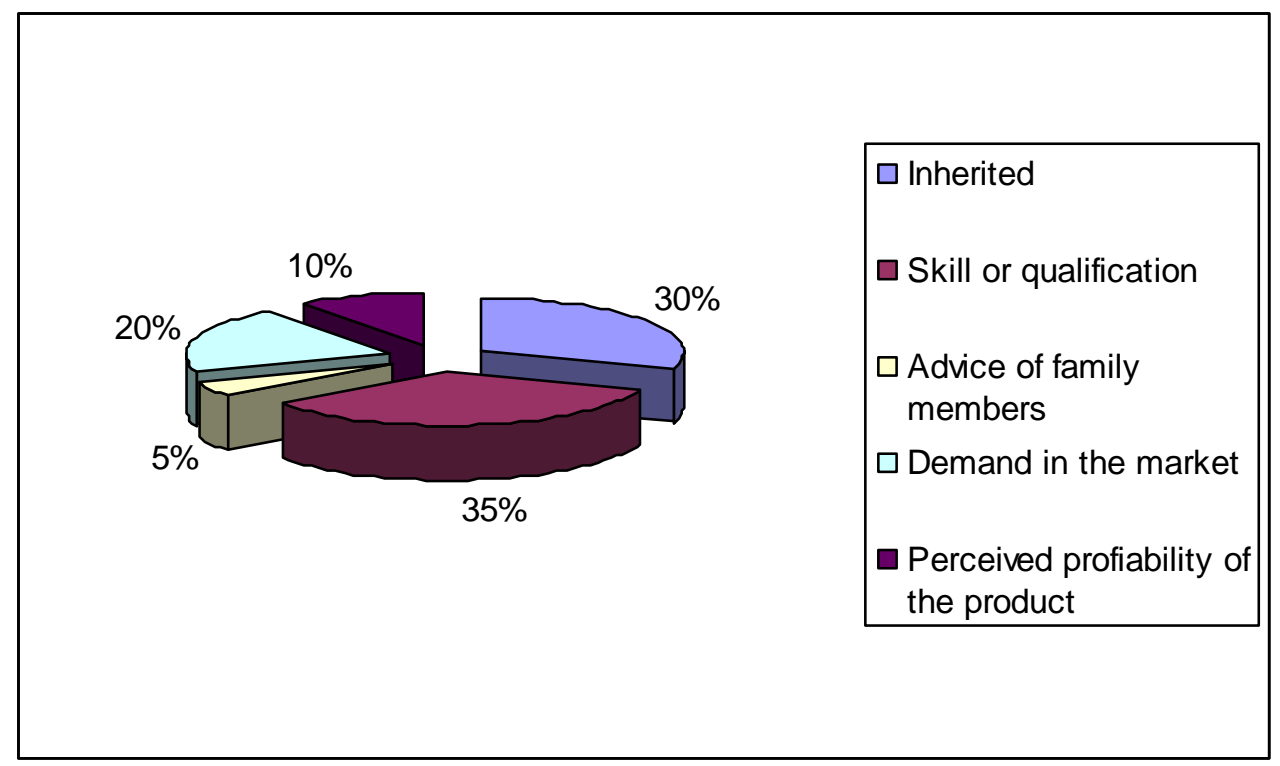




\section{3: Problems experienced during business operation:}
a) Financial
c) Environmental support
e) Access
to information
b) Family support
d) Education

I asked above question to know what problems faced during the business. Generally following types of problems perceived during the of the business operation, that is, financial problems, family support, environmental support, lack of education, access to information.

Out of 30 respondents, $30 \%$ women face problem in environmental support, $25 \%$ face financial problems, $20 \%$ face problem access to information, $15 \%$ face education problems and $10 \%$ women face problem in family support.

From the analysis of above question it is clear that more or less all women entrepreneur of Kohat city of KPK-Pakistan face problems in business although in start or in running. Mostly women face financial problems, problems in environmental support and problem in access to information in running business

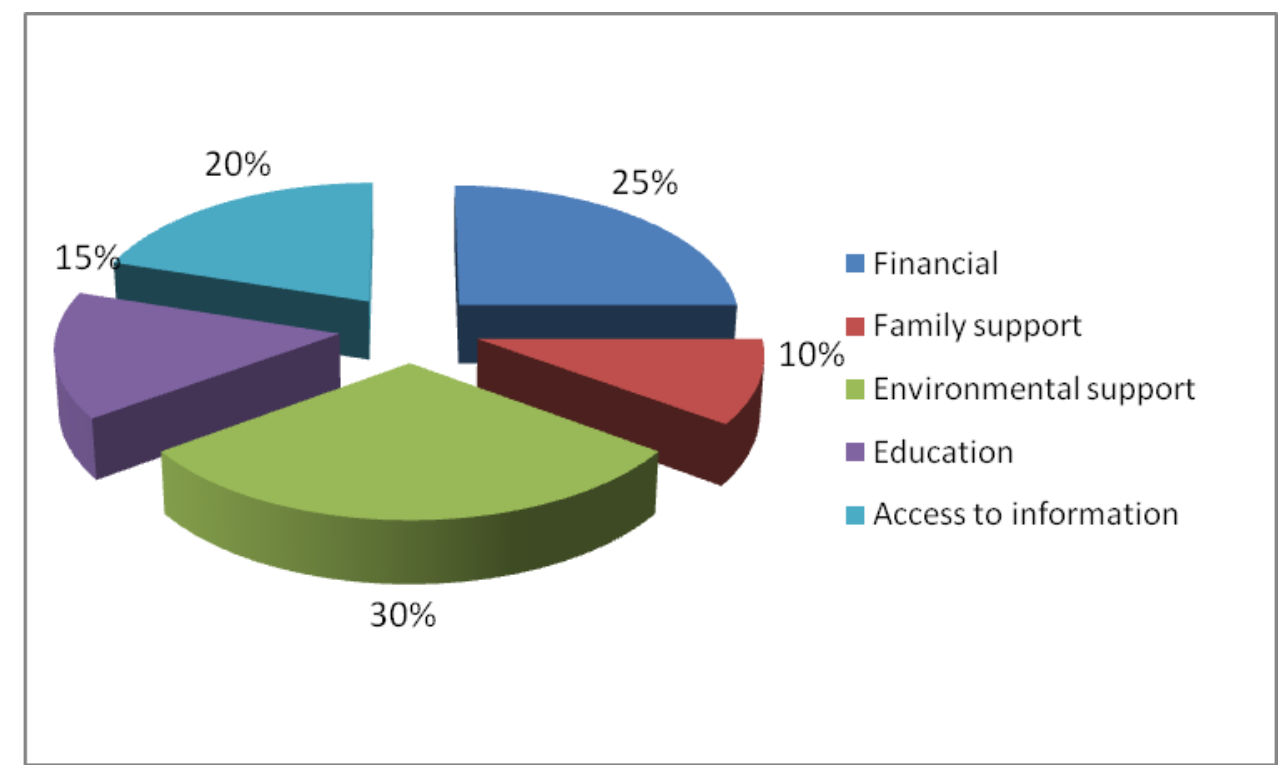

\section{4: Dose "Gender base discrimination" affect the Women entrepreneurs?}

This question gives the grading about women entrepreneurs that how they feel about gender base discrimination. While doing research, it come to know that women entrepreneurs of Kohat city of KPK-Pakistan affected by gender base discrimination. Out of 30 respondents, $9.16 \%$ responds grade $1,7.5 \%$ responds $2,21.67 \%$ responds $3,14.16 \%$ responds $4,21.67 \%$ responds $5,10.83 \%$ responds $6,2.5 \%$ responds $7,1.67 \%$ responds 8 , $7.5 \%$ responds 9 and $3.33 \%$ responds 10 . 


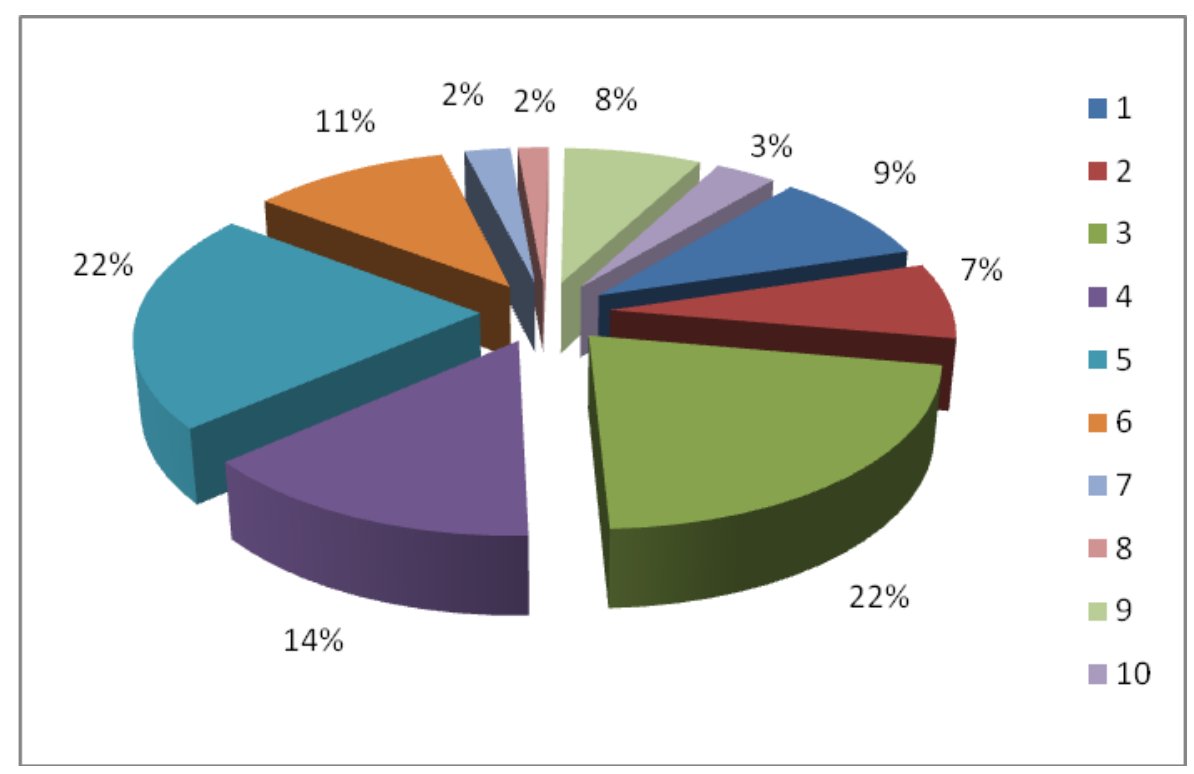

5: Dose Women entrepreneur faces unfavorable market behavior?[(a)Yes b) $\mathrm{No}]$

Through this question it is measured that to what extant women entrepreneur face unfavorable market behavior.

Out of 30 respondents $58 \%$ of the respondents said that Yes, they are facing unfavorable market behavior, $42 \%$ of the respondents are saying No i.e. that they are not facing unfavorable market behavior.

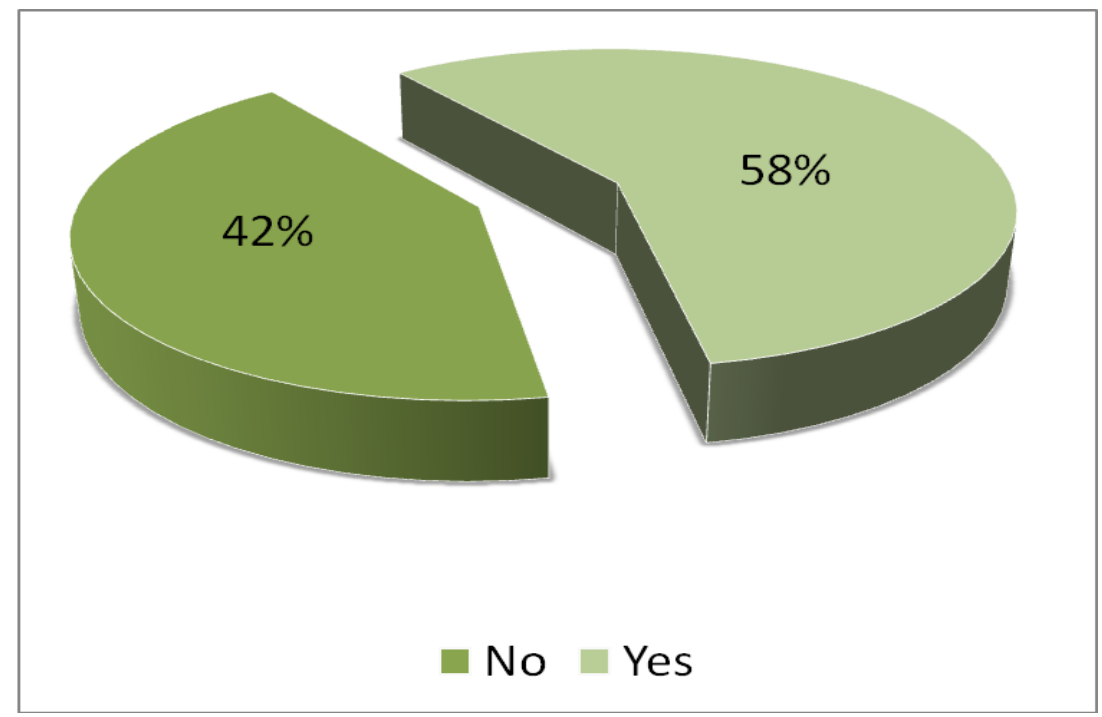

6: What Family/social issues do you face?
a) Non-supportive family
c) Time distribution between family and business
b) Household responsibility/engagements
d) Children were neglected 
Through this question it is calculated that either there are any family or social issues face by women entrepreneur of Khyber Pakhtunkhwa and which types of family/social issues they are facing.Out of 30 respondents $33 \%$ of respondents faced problem in time distribution between family and business, $27 \%$ face issue in Household responsibility/engagements, $25 \%$ face Children were neglected and rest $15 \%$ face non-supportive family issues.

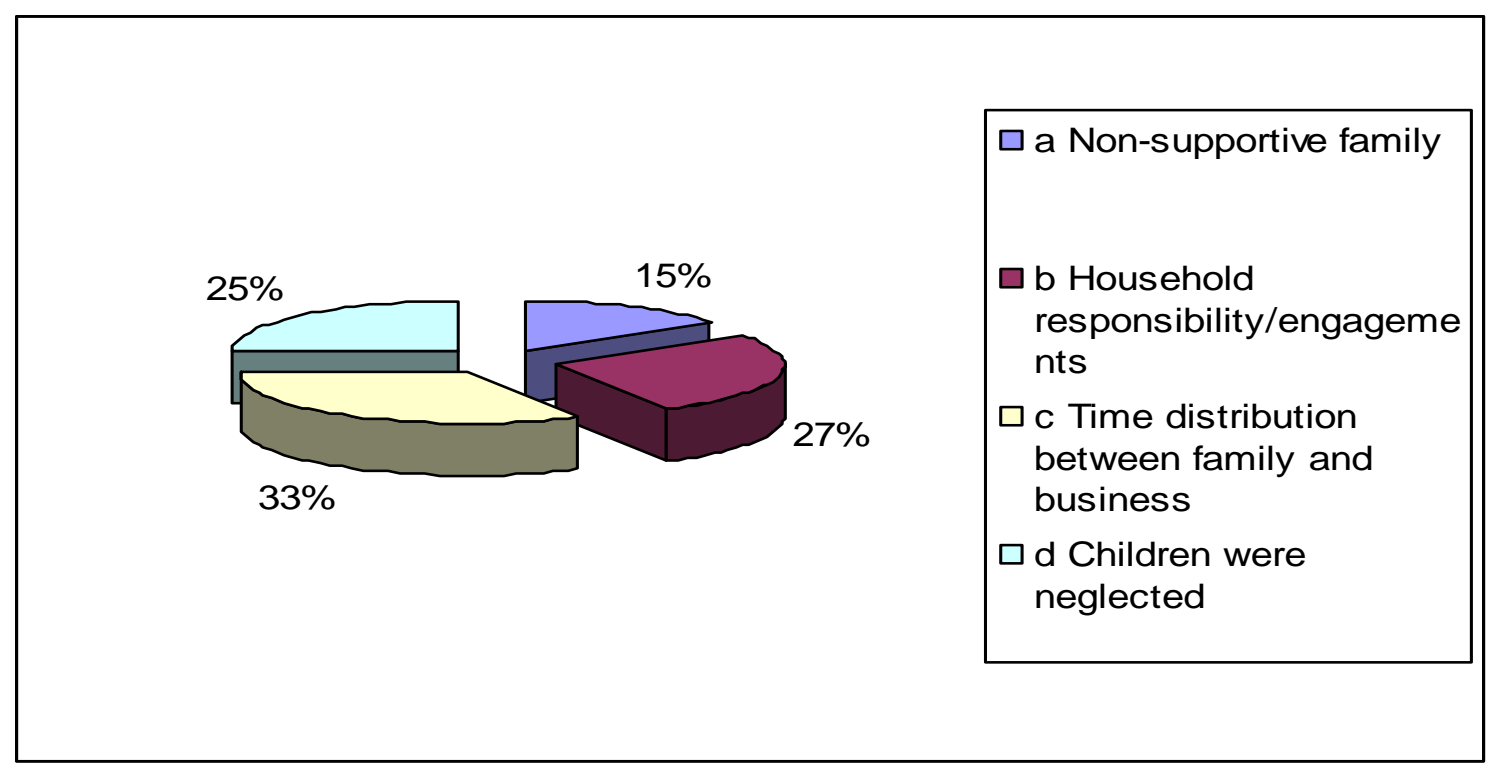

\section{7: What Financial problems faced by women entrepreneur?}
a) Shortage of working capital
c) Repayment of loan
b) Shortage of funds for expansion
d) others (specify)

This question helps us to know which types of financial problems are facing women entrepreneurs of Kohat city of KPK-Pakistan.

Out of 30 respondents $35 \%$ women entrepreneur face shortage of working capital in their business, 30\% women entrepreneur face problems in repayment of loans, 25\% women entrepreneur face shortage of funds for expansion and other $10 \%$ women entrepreneur face different financial problems like, problems in recovery of credit, problems in avail loans from financial institutions and problems in other financial decision. 


\section{Macrothink

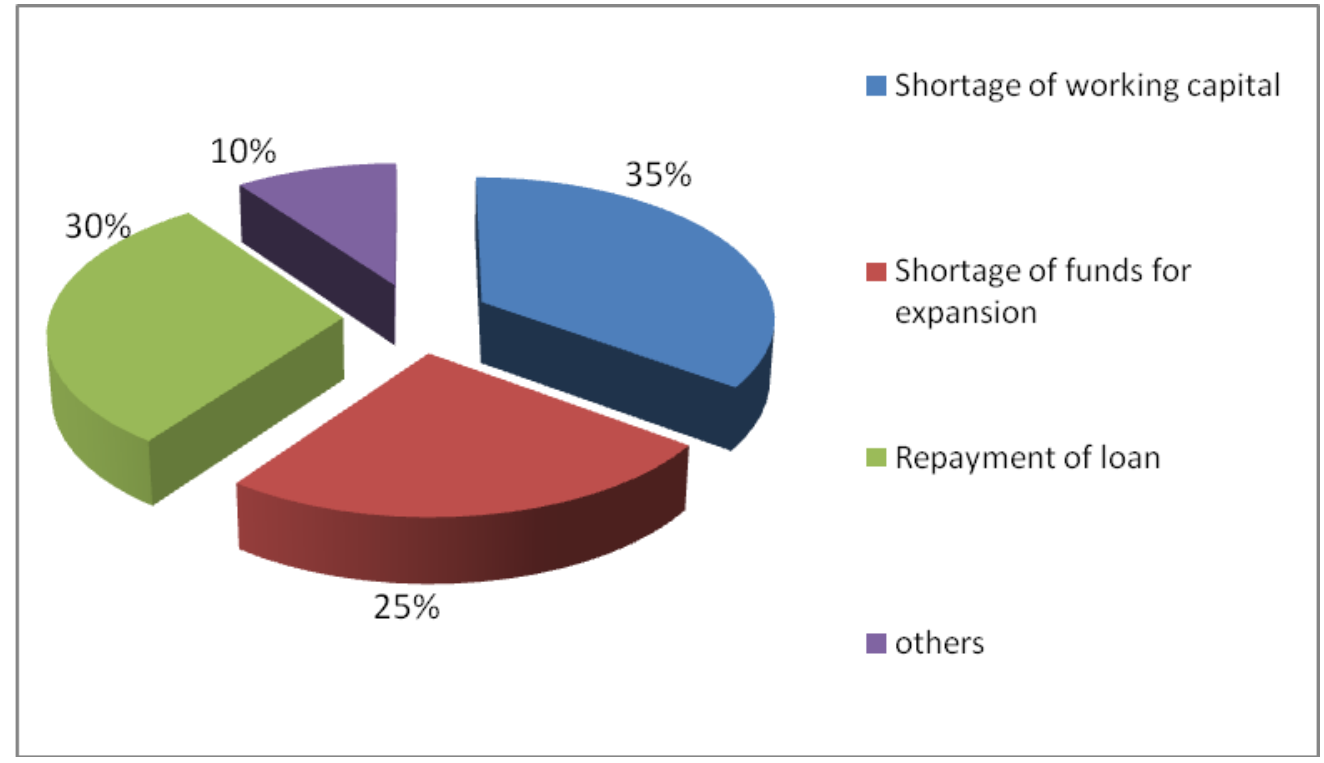

\section{8: Which types of government related issues you face?}

a) Government departments were not cooperative. b).Government policies/ regulations were stringent. c).Bribery. d) Harassment by Tax department.

From the above question, I get to know that which types of government related issues faced by women entrepreneur while running their business.

Out of 30 respondents $34 \%$ women entrepreneur face problem of bribery in government related issues, $32 \%$ face harassment by Tax department, $20 \%$ said that government policies/regulations were stringent and $14 \%$ said government departments were not cooperative enough to resolve their issues and help them.

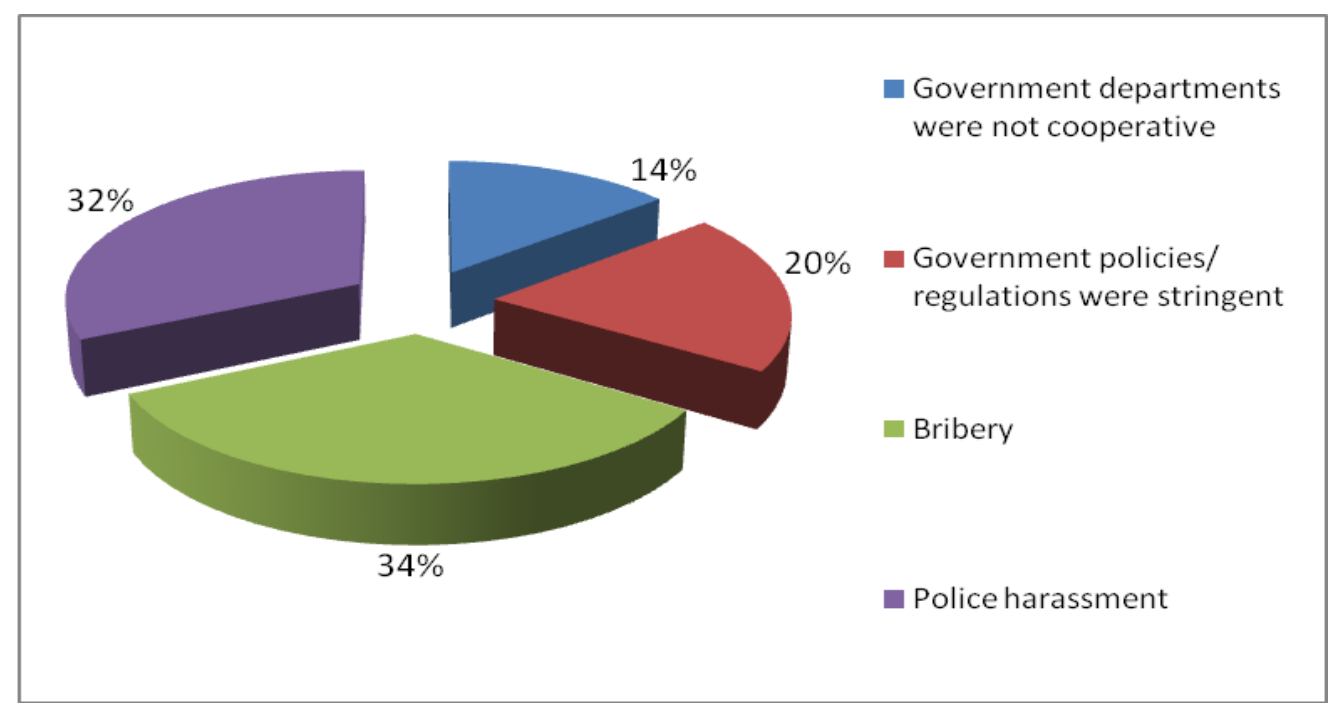




\section{9: In your opinion, lack of Education adversely affect women entrepreneur?}

From above question it is investigated that either women entrepreneur of Kohat city of KPK-Pakistan are aware about the importance of education or to what extent they are affected by the lack of education.Out of 30 respondents $10.5 \%$ respondents grade $1,9.56 \%$ grade $2,21.80 \%$ grade $3,15.68 \%$ grade $4,21.76 \%$ grade $5,9.57 \%$ responds $6,3.50 \%$ responds $7,2.34 \%$ responds $8,1.83 \%$ responds 9 and $3.46 \%$ responds 10 .

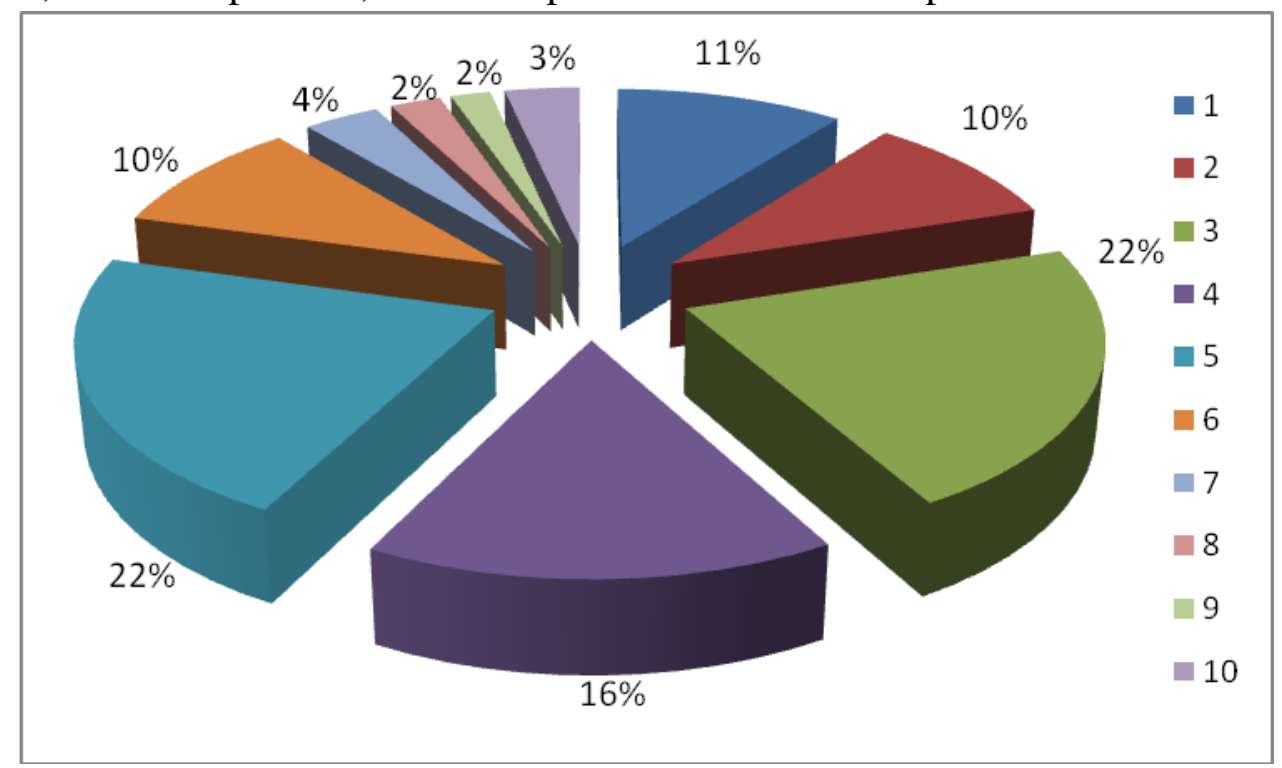

\section{Conclusions and Recommendations:}

Government of Pakistan is trying to encourage female entrepreneurship especially SMEs level because entrepreneurship contributes towards the economic development of a country by creating employment, product/service provision and reducing poverty (Samli, 2002). Such positive relationship between entrepreneurship and economic growth has been supported by Carree et al.,(2002); Schumpeter, (1934, 1950 and 1954) and Brown et al., (1998).

In Pakistan and particularly in KPK province women entrepreneur face gender base discrimination. Moreover, business conditions are not favorable for women in male dominated society, like dealing with men is difficult for women, lack of protection etc. Thus, women entrepreneur of KPK should be made aware about their rights. There is also need to change the perception of men towards women entrepreneur. Women (more than $50 \%$ of population) should be encouraged to participate in business activities. They should be respected and be considered trustworthy.

Similarly, Women need to honest about her strengths and weaknesses to become an entrepreneur, and no matter what business she starts because sometimes it is hard to know our own strengths. If you are uncertain what your hidden skills and talents are, ask family and friends who know you. You still have skills that may be marketable if you can identify them. 
Further, media must play its important role through publishing/broadcasting successful women entrepreneur's stories by showing them as positive role models. This will not only create positive impact on rest of the women of our society to make decision and choices about their careers but will also generate appropriate atmosphere for their family members to allow them to enter into business activities.

Starting your own business will require time, energy, and sacrifice. If they choose something that does not interest her, or worse, something her hate to do, she will find it harder to succeed so women should choose something they are passionate about. There are many new careers she can enter into with a certificate instead of a degree. Certificates often take less than a year to earn, and, in some cases, only a few semesters. She should check with local community college to see what certificate programs are offered in her area.

Networking is too much important issue which must be discussed here. Networking involves actively cultivating relationships with people, businesses, community leaders, and others who present possible opportunities for your business. Networks are major sources of knowledge about women's entrepreneurship and this networking is considered as a valuable tool for development and promotion of entrepreneurial culture in the society. Similarly this networking is one of the best ways to market their business .For this purpose and to create more awareness in the society, local media for instance cables networks, and print media etc. can play an effective role. Policy makers should promote the networking of associations and encourage co-operation and collaborations among national and international networks to facilitate entrepreneurial endeavors in the economy. In this context, chambers and different associations should play its role more prominently.

In Pakistan, particularly in KPK, there in no concept of training before starting business. Thus, in terms of training and development of entrepreneur, government should increase number of training centre to facilitate or provide technical, management and entrepreneurial skills as well as legal matters training and assistance in marketing activities. Moreover, exhibitions should be organized with mutual collaboration on order to promote entrepreneurial culture in our society.

In the same way, education level of women entrepreneur of Khyber Pakhtunkhwa is not satisfactory; government should encourage and provide quality education to women of Khyber Pakhtunkhwa in terms to cope up with this serious issue because lack of education creates numbers of problems.

In order to promote entreprenruial culture in our society, both financial and moral support of immediate family members and more opportunities seeking motivation is an important factor for the development of a country like Pakistan with special reference to Kohat city of KPK. Since, mostly businesses in KPK are family oriented, therefore informal parental relations can play very important role in this regard especially from family members in order to 
encourage entrepreneurial culture in our society. Family members should encourage theirs young generation to become jobs creators not the jobs seeker.

Moreover, access to the resources is other important issue which must be addressed in order to exploit opportunities well before time. There is a need of more flexible banking policies to give loan at minimum markup with easy repayment options by considering the unavailability of collateral and their incapability to build up feasible business plans. Thus, in KPK province facilities should be provided to business community to get capital from one window operation through formal source of finance instead of informal sources because in most of the cases start-up capital were provided by their family and friends due to easy access and immediate availability without any lengthy procedure and proper collateral requirements. This creates demand for enhancing the role of supporting agencies like SMEDA, SME bank and first women bank etc. Further, time constraint while taking the loan should be reduced, so that an applicant can get loan at the right time for utilization without too much complicated procedure. In this context, government should make polices and make sure of its proper implementation in favor of business community in KPK province. Taxes should be reduced and loans-sanctioning procedure must be simplified.

At the end we can say that women entrepreneur should have enough information about their business, skills, marketing knowledge, and easy access to financial capital and have strong networking and representation.

\section{References:}

Allen, S., \& Truman, C.(1993). Women in business: Perspectives on Women Entrepreneurs. London: Rout ledge Press.

Bygrave,W.D. (1994) The Portable MBA In Entrepreneurship.John Wiley and Sons, New York.

Brown, S.L., Eisenhardt, K.M., (1998).Competing on the edge. Harvard Business School Press, Boston.

Carree, M.A., Stel, A. van, Thurik, A.R., \& Wennekers, S. (2002). Economic development in business ownerships: An analysis using 23 OECD countries in the period 1976-1996. Small Business Economics: An International Journal, 19(3), 271-290.

Hisrich, R.D. \& Brush, C.G. (1988) Women entrepreneurs:problems and opportunities. In Women's Careers,Pathways and Pitfalls (Ed. by S. Rose and L. Larwood),pp. 193-207. Greenwood Press, New York.

Hisrich, R.D. \& Peters, M.P. (1989) Entrepreneurship,Starting, Developing and Managing a New Enterprise.Richard D. Irwin, Boston.

Lerner, M., Brush, C., \& Hisrich, R.(1997)“Israeli women entrepreneurs: An examination of factors affecting performance”. Journal of Business Venturing, 12, 315-339.

Pakistan Daily (2010) Pakistani Entrepreneurs to Get International Recognition 
http://www.daily.pk/?p=20735

2012, Vol. 2, No. 1

Peterson, R. \& Weiermair, K. (1998) Women entrepreneurs,economics development and change. In Journal of Development Planning, Entrepreneurship and Economic Development (Ed. by H. Lebinstein and D. Ray), pp.95-111. United Nations Publication, New York.

Samli, A.C. (2002).Entrepreneurship and small business development: the necessary ingredient for economic progress.11th World Business Congress, 10-14, 2002.

Samina Kamal(1997).Women, empowerment and poverty alleviation in South Asia: The dual benefits of Microcredit p. 114, South Asia Poverty Alleviation Program, UNDP.

Schumpeter, J., (1934). The Theory of Economic Development. Harvard Univ. Press, Cambridge.Mass.

Schumpeter, J.(1950). Capitalism, Socialism, and Democracy. Harvard university Press, Cambridge, Mass.

Schumpeter, J. (1954). History of Economic Analysis. Oxford University Press, New York.

Sirageldin, I., Sorkin, A. \& Frank, R. (1990) Research in Human Capital and Development. Jai Press, UK.

Stiglitz Joseph(1998).Gender and development: The role of the state, Gender and Development Workshop, Washington, DC.

UNDP(2006) Preparatory Assistance (PA) Document Number: PAK/96/016 — Facilitating women's mobility, UNDP Pakistan.

World Bank(1999).Country gender profile of Pakistan, World Bank, 1999 Washington DC.

Wees. C. Van Der \& Romijn, H. (1987).Entrepreneurship and small enterprise development for entrepreneurs in developing countries, International Labour Office. Geneva. Entrepreneurship and Regional Development,9(3),211-20.

Zahir Ahmad Sulehri (2010) Opportunities for young Pakistani entrepreneurs http://www.daily.pk/?p=21660. 